\title{
Reframe policymaking dysfunction through bipartisan-inclusion leadership
}

\author{
John W. Straka ${ }^{1}$ Brenda C. Straka ${ }^{\mathbb{1}}$ \\ Published online: 29 April 2020 \\ (c) Springer Science+Business Media, LLC, part of Springer Nature 2020
}

\begin{abstract}
Persistent policy failures have been examined in recent years with a focus on the role of political systems. We evaluate the growth of dysfunctional policymaking in the U.S. and propose a countering approach. Policy failures often reflect partisan policy stalemate, errors or unintended consequences, polarized extremism or imbalance, or partisan reversals with changes in power. Extremes in partisanship are not new historically, but growing policy failures due to negative partisanship have now severely damaged public trust. More "party blind" conditions in policy formulation may be able to renew a more productive social contract. We propose a disruptive presidential leadership approach of bipartisan inclusion to seek to reframe the partisan divides, counter negative partisanship and extremes, re-establish better policymaking interactions, and improve governance and policy outcomes. Dysfunctional policymaking has been attributed to Republicans and Democrats in a Prisoner's Dilemma. Iterated Prisoner's Dilemmas often lead to higher rates of cooperation, and similarly, historical policymaking included greater cooperation, but in recent decades the bipartisan norms of governance have substantially eroded. We describe three complementary explanations, which suggest that non-cooperative partisan policymaking has become self-reinforcing, and institutional changes to promote cooperation should focus on lowering the risk-adjusted cost-benefit ratio, making cooperation safer and more attractive for policymakers.
\end{abstract}

Keywords Government dysfunction · Prisoner's Dilemma · Zero sum · Polarization · Party loyalty $\cdot$ Stag Hunt $\cdot$ Bipartisan

John W. Straka

jwstraka789@gmail.com

Brenda C. Straka

brenda.straka@duke.edu

1 Model Risk Professional, Oakton, VA 22124, USA

2 Social Psychology, Duke University, 417 Chapel Dr, Durham, NC 27708, USA 


\section{Introduction}

Persistent policy failures have been examined in recent years with a focus on the role of political systems (Howlett et al. 2015; Derwort et al. 2018; Schultz 2008). This paper evaluates the growth of dysfunctional policymaking in the U.S. compared with earlier history and proposes a countering approach. Policy failures often reflect partisan policy stalemate with a drifting status quo, errors or unintended consequences, polarized extremism or imbalance, or partisan reversals with changes in power. Extremes in partisanship are not new historically, but growing policy failures due to negative partisanship have now severely damaged public trust in institutions. We describe three complementary explanations, which suggest that non-cooperative partisan policymaking has become self-reinforcing, and institutional changes to promote cooperation should focus on lowering the risk-adjusted cost-benefit ratio, making cooperation safer and more attractive for policymakers. We propose a disruptive new form of presidential leadership joined with other approaches to improvement.

Government policymaking dysfunction from partisan polarization is generally seen as a corrosive failure of institutions (Thurber and Yoshinaka 2015). Much of it being reflected in a lost sense of governing trust (or social contract) and many deadlocked unmet policy needs. Over $80 \%$ of Americans have said the country is greatly divided about important values, with $77 \%$ saying they are dissatisfied with the state of politics (Summers 2018). About $70 \%$ to $90 \%$ have said they are very concerned with the deepened polarization, bitterness, disrespect, contempt, and even hatred between groups (Brooks 2018a, 2019). A December 2018 New Hampshire poll found more voters viewing political dysfunction (74\%) and disunity (68\%) as a threat to America than any other major issue (Troiano 2019). After the 2018 midterm elections, The Economist (2018) emphasized America's divisions and prospects for poor policymaking with both sides declaring victory. Most of the public expected gridlock through 2020 (Pew Research 2018), and, as in previous years, this has been a good general forecast.

With many unaddressed policy tradeoffs and needs, political candidates can seek or rise to power through major policy failures, failures that are inflated, embellished, and aggrandized, or alignment with specific voter protest or identity groups. Unmet needs in turn encourage more power-play policymaking or obstruction (e.g., laws passed or blocked along party-line votes) and more ominously, authoritarian tendencies. To counter these trends, we suggest that a new form of social contract between the dominant governing parties may be possible through a reframing of policymaking interactions to encourage better governing norms. A recent RAND study (Kavanagh and Rich 2018) found that in earlier periods of turmoil, a revival of factual policy analysis and journalism and a focus on holding leaders accountable helped clarify the line between opinion and fact. A similar renewal today might re-orient policymaking to more fact-based rationality, assessment, and purpose (Perl et al. 2018). Our proposal requires leadership but no new laws. More "party blind" "auditioning" conditions in policy formulation may better balance and improve cooperative policymaking. We propose a new presidential administration with bipartisan leadership inclusion in policymaking. 


\section{Empirical and observational evidence}

A broad analysis by Gehl and Porter (2017) finds over many years:

(1) a clear trend decline in the numbers of laws passed by Congress;

(2) a clear trend increase in the number of "salient issues" deadlocked in Congress;

(3) a sharp trend decline in the number of bipartisan conference committee reports;

(4) an increasing proportion of party-unity votes;

(5) much lower bipartisan vote support after the 1990s for "landmark legislation;"

(6) a low recent share (about a third) of legislation introduced with bipartisan cosponsors; and

(7) a declining much lower share of moderates in Congress, especially after the early 1990s.

From empirical studies showing policy stalemate trending upward along with party polarization, commentators have noted the growth of policy problems and failures mounting from "kicking the can down the road" and "drifting" outcomes that perpetuate the status-quo (Lee 2015). Prior to 2017, recent decades of legislative changes or corrections in policy have not appeared to systematically advantage either conservatives or liberals (Curry and Lee 2019; Lee 2015). With a few landmark exceptions generally realized through unilateral power, the limited laws that have passed have not included many potential larger or more difficult changes. More difficult policy improvements requiring broader bipartisan support persistently fail to succeed legislatively or even reach the floor of the Senate or House for votes. ${ }^{1}$

In 2017-2018, a stronger partisan tilt through unilateral power became prominent (with the GOP President, Senate, and House before 2019). New administration policies (several more extreme), judicial appointments, and legislation or legislative attempts, with Congressional support or acquiescence, rescinded or reversed the directions of many previous Obama administration policies and longstanding bipartisan approaches. ${ }^{2}$ The shift of the Supreme Court and judiciary to the right has grown as Trump and the GOP-controlled Senate have enacted the long-term strategy of the Federalist Society and beyond with several doctrinaire judges appointed despite ratings of 'unqualified' by the American Bar Association. (In comparison, none of Obama's judicial nominees were rated unqualified.) Senate denials blocked many of Obama's nominees, culminating in the unprecedented 9-month refusal to give Obama's last high-court nominee a hearing. Since the power shift in Congress after the 2018 midterms, GOP Senate leader McConnell has returned to his previous obstructive tactics, blocking from consideration nearly 400 bills passed in the Democraticcontrolled House (Axelrod 2019; Martin 2019).

Policy failures from the pattern of non-cooperative partisan stalemate have led to recurrent tragedies or mounting issues from: (1) gun violence and deaths, (2) eroding infrastructure, (3) failed immigration reform, (4) growing climate and environmental risks, (5) health threats and inefficiencies despite costly systems, (6) failed trade- and technology-adjustment support causing uneven employment, (7) unequal access to rights and opportunities

\footnotetext{
1 The missing policy improvements may be typed into ideological, imposed, reluctant and inadvertent policy inaction (McConnell and 't Hart 2019).

2 To be sure, some comparatively modest bipartisan legislation also passed, as in previous years, and likewise for funding to meet national emergency needs.
} 


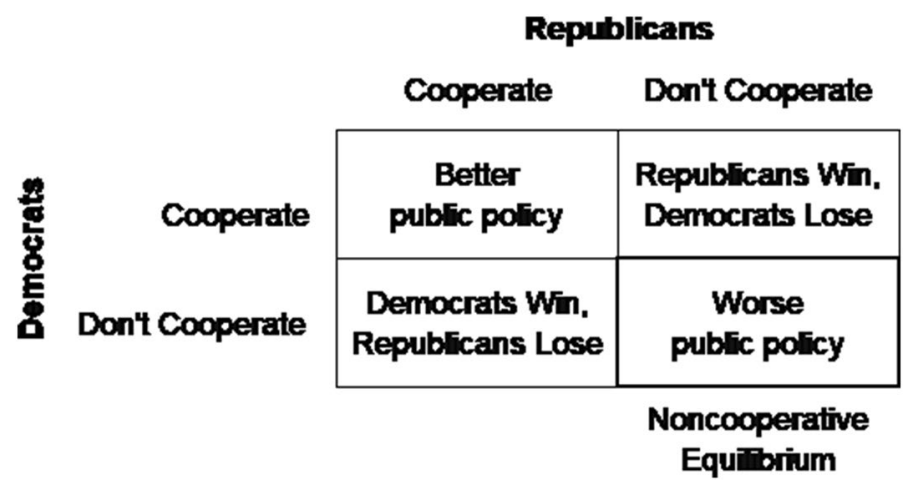

Fig. 1 The policymaking Prisoner's Dilemma

with unshared economic growth and growing inequality, (8) unsustainable entitlements, (9) the general pattern of government shutdowns/threats and planning uncertainty, (10) inconsistent foreign policies with mixed responses, (11) unclear preparedness for growing cyber threats, and on and on. Difficult policy problems have been made worse by government dysfunction with inabilities to address tradeoffs, plan appropriately, and devise more effective approaches. Even the U.S.' severities of the 2007-2009 Great Recession and the 2020 coronavirus pandemic can be traced in considerable degree to the non-cooperative policymaking equilibrium. Policy failures have multiple causes of course, which can interact, but at root, the costs of policy stalemates sooner or later have often been high and tragic.

Policymaking dysfunction in the U.S. has been described as the outcome of Republicans and Democrats in a Prisoner's Dilemma where mutual cooperation is generally better than divided non-cooperation, but each party is independently incented to not cooperate (Atkins 2017; Contrisciani 2018; Desai 2017; Kamer 2018; Masket 2017; Picardo 2019; Easley et al. 2015; The Economist 2013; Sallet 2011). The Trump era has deepened these concerns (Brooks 2018a, b; Bauman 2018; Gammon 2019).

From each party's perspective "winning" is better than mutual cooperation while the "sucker" outcome (cooperating while opponents do not) is the worst, as shown in Fig. 1. This reflects policy perceptions, not objective policy quality per se.

Such incentives between opposing policymakers have existed throughout America's history. This is an Iterated Prisoner's Dilemma (IPD) repeated many times over, essentially in perpetuity. Historically, policymakers were able to restrain and discipline themselves (e.g. through the rules of Congress and general governing norms) to act more consistently with the ideal that democracy requires power sharing and compromise, not "win at all costs" (Levitsky and Ziblatt 2018). In recent decades, instead, policymakers have increasingly failed to bridge significant differences. Polarization has whipsawed policies over time with changes in power and left many festering problems with little to no sustainable progress on many policy needs.

Ironically, Trump's electoral-college victory in 2016 was an exploitation of the noncooperative policymaking equilibrium. Before election (and ever since), Trump inflated, aggrandized, and branded a large share of past policy failures or shortcomings, along with any competing or opposing politician, as a "total failure," a "loser," and so on (a common tactic of demagogues with authoritarian ambitions). Given the policy problems made worse by non-cooperative stalemate, and a groundswell of public mistrust and disgust, "establishment" politicians were vulnerable to this line of attack albeit crudely ill-informed 
and often plainly and unabashedly dishonest. Trump took an already established phenomenon to new heights, wherein renegade political behavior has paid individual political dividends to its purveyors (Rauch 2016).

Many voters took a protest-vote gamble on Trump as a "disruptive outsider" (Henriques 2017) who could "make sensible business-like deals" in Washington (no matter that his actual business record, other than in branding his name, was very weak) — but almost exactly the opposite has occurred since his election. He has made the problems of political polarization - punctuated by the 2019 House impeachment of Trump followed by Senate "forgiveness" - and resulting policymaking stalemates much worse. Many Democrats now believe, in Prisoner's Dilemma terms, that their party must stop "playing the sucker" (cooperating while the other party does not) because America no longer has a rational political system (Paur 2016; Atkins 2017). Republicans have likewise accused Democrats of refusing to cooperate in policymaking (Chantrill 2013), and Trump attempts to do the same. Nothing has really changed in the policymaking problem except for a highly energized opposition to Trump. Trump's divisive and authoritarian-leaning approach has been precisely the wrong kind of disruption needed to counter the non-cooperative equilibrium in policymaking stalemates.

\section{A different disruptive strategy to counter the non-cooperative equilibrium}

In view of the causes of persistent policymaking dysfunction, more "party blind" "auditioning" conditions in policy formulation may better balance and improve cooperative policymaking. We propose a leadership strategy of bipartisan inclusion in a presidential administration to encourage such a change.

A bipartisan presidential candidacy has been variously proposed, advocated, and considered both recently and in the past (Glover 2018; Bowden 2019; Troiano 2019; Troiano and Wheelan 2019) although this approach is arguably impractical. A late 2018 poll of New Hampshire voters found that $61 \%$ said they would support their preferred candidate forming such a "unity ticket" of Democratic and Republican running mates (67\% of Democrats, $65 \%$ of independents, and 51\% of Republicans) (Troiano 2019). Various observers, however, have argued against such proposals - or any form of unity in 2020 (Shepard 2017; Smith 2018). Many Democrats now see the GOP's leadership as incapable of meaningful compromise or "unity" (Tomasky 2019b), which calls for staunch political opposition and partisan elections, not "dreamy" calls for unity. For a candidate from either party, a unity ticket risks splitting party-line votes and handing easier victory to the opposingparty candidate (a large percentage of Independent voters "lean" toward either Republican or Democrat based on Gallup and Pew Research polling). The last unity ticket was seen in 1864. Thus, even centrist presidential candidates seem very likely to continue to avoid any bipartisan candidacy.

Bipartisan inclusion in a presidential administration after election does not require a unity ticket, however. A group of party candidates or a popular leading candidate can instead announce that if elected president, he or she will offer a policy-advising role to the losing-party candidate or other opposition-party leader(s) and include a diverse-party mixture of advisors overall in the new administration. This plan will seek a new form of governing social contract through presidential leadership, which requires no new laws. Past 
administrations have retained in their leadership only a small number of opposing-party functionaries at times (typically holdovers). ${ }^{3}$

By including policy-experienced non-extremist leaders from both the winning and opposition parties on the same operational administration "team" with mutual interests in superordinate goals, this proximity in executive-branch policy formulation may lower the risk-adjusted costs and raise the mutual-party-leader payoffs of policymaking cooperation. Resulting policy changes reflecting bipartisanship from the executive federalism of this new administrative state, and bipartisan-supported proposals from this new type of administration, could both enact more balanced and durable executive-branch policies and help change the public discourse to achieve more balanced and durable policymaking legislation. Through this disruptive reframing, key national leaders could thus potentially be nudged (Hallsworth and Egan 2018) away from policy gridlock, toward greater trust, and into more productive and fact-based, effective and balanced policies and governance.

The planned offer to losing opposition-party leadership should exclude any chronically uncivil, corrupt or untrustworthy, ruthlessly partisan, or aggressively extreme opposingparty candidate or leader (e.g., Trump, or anyone with such a divisive approach)—who would not be suitable for any new bipartisan policymaking administration. The remaining Democratic candidate, Joe Biden, could pursue this choice today, for example, excluding Trump, but stating that if elected he will offer a policy-advising role to some of Trump's past GOP opponents, such as William Weld, Joe Walsh, Jeb Bush, or John Kasich. This general type of approach would: (1) explicitly offer bipartisan policy-advising roles to trustworthy counterparties, (2) isolate divisive leaders like Trump (and other supportive enablers and noncooperators), (3) encourage more preferred alternative non-divisive candidates and thinking in Congress, and (4) diminish the partisan reelection prospects of divisive leaders. A credibly unifying presidential candidate from either party could plan and pursue such an approach.

Under this approach, the election will still have policy consequences of course. While drawing on a more bipartisan diversity of viewpoints and advice, the elected President will still be the final decision maker within the new administration. The planned offer(s) to opposition-party leaders can most likely be advisory roles, or perhaps cabinet positions or similar suitable roles at times. (Congress needs to confirm any opposition-party appointments but will likely do so after an election win for any candidate with such an announced bipartisan-leadership plan.) Career subject matter experts across government who have historically served presidential administrations from both parties can be most effectively leveraged in teams with bipartisan leadership inclusion, although final decision makers at administrative levels (determining recommendations passed to higher-level leadership or smaller policy details in practice) may still be from the elected President's party or other leadership of the President's choosing.

This new approach could begin a reframing of key party-leader interactions in policymaking. It does not require unity-ticket partners to join and campaign together, and it offers any new President flexibility in the offered policy-advising roles of opposing-party views. The approach signals a broader customizable commitment to bipartisanship. The general plan of offering a role after election to opposing-party leadership also does not waste

\footnotetext{
${ }^{3}$ In rare exceptions, a higher-level subject matter or policy expert willing to work for the opposing-party president has been selected. Bipartisan commissions have also had increasingly less influence and effect on policies.
} 
potential "loyal opposition" leadership contributions in ideas and experience, as generally occurs in administrations following each winner-party-take-all election cycle.

Any new administration with bipartisan inclusion should be more than symbolic, and intelligently managed - the new President will be the final decision maker, but he or she should take clear steps to include bipartisan diverse views in decision making. Ironically, given the common zero-sum views in policymaking circles today, a president leading in a disruptively bipartisan way could have more truly effective and lasting leadership power by sharing rather than hoarding the input flow through executive policymaking channels. Policies and decisions formulated with bipartisan support are more likely to be politically robust and sustainable, and diversity and balance can avoid "group think," promote creativity, and achieve better decisions (Janis 1972; Tetlock 1979; Mccauley 1989; Whyte 1998; Cialdini and Goldstein 2004; Paulus and Nijstad 2003; Hong and Page 2004).

The most effective policymaking leverage of a new bipartisan-inclusion administration may be realized through two other pillars added to this approach. First, while bipartisan inclusion in executive-branch processes could help mend some of the systemic problems of public discourse today, breaking Congressional stalemates for bipartisan-supported legislation may often require enough cooperative or centrist-bloc swing votes (Wheelan 2013, 2019). Second, although it must be approached cautiously, the polluting effects of the rise of partisan media and spread of falsehoods may be countered with a re-establishment of some new modernized and carefully balanced form of the historical "fairness doctrine" in broadcasting (Avlon 2019; Matzko 2019; Rendall 2005). ${ }^{4}$

As with any disruptive organizational change (especially a cultural shift), bipartisan inclusion within the executive branch may face several transition and management challenges. Nonetheless, American voters weary of dysfunctional divisions, Trumpian-style antics, and the disturbing patterns and trends of poor policy and governance outcomes could come to support and generally prefer this type of electoral and governing approach in 2020 or some future year.

\section{The perpetuating non-cooperative status quo}

Although self-interest leads to mutual non-cooperation in a one-shot Prisoner's Dilemma game, if the game or situation is repeated many times over, or with collaboration or reputation effects with informational asymmetries, players typically cooperate conditionally, punishing defectors through tit-for-tat for example, and higher rates of cooperation tend to evolve and prevail contrary to the Nash prediction (e.g. Flood 1952; Axelrod and Hamilton 1981; Axelrod 1984; Axelrod and Dion 1988; Chong et al. 2007; Kreps et al. 1982; Stewart and Plotkin 2013; Seltzer 2016). Likewise, historical policymaking included greater cooperation. In recent decades the bipartisan norms of governance have substantially eroded as failures of cooperation have undermined or stymied the ability of policymakers to improve

\footnotetext{
4 All of these approaches are complementary to further approaches to reducing the negative policymaking impacts from polarization and noncooperative governance. Institutional remedies show promise despite being generally slow-moving changes or legislation (e.g., Mann and Ornstein 2012; Weiser and Bannon 2018; Wheelan 2019). An important set of approaches seeks to address factors in the social psychology that sustain the sharp divisions and unwillingness or inability to effectively cooperate toward the advancement of larger common goals. These approaches focus on grass roots change in individual social responsibility, social activism, political activism, and social interactions to promote greater tolerance, fact-based assessments, and bipartisan dialogue (Brooks 2019; Hartle 2019; Freedman 2019; Haynes 2018).
} 
many governance outcomes-especially in larger or more significant and durable ways. A general explanation of cooperative failure, as suggested by Stewart (2015), is that cooperation fails when the ratio of costs to benefits becomes too high.

Conflict and debate can be productive within governing norms promoting cooperation. Cooperation can draw on mutual tolerance of opposing political parties and perspectives as legitimate, searches for common ground, thoughtful tradeoffs, and trust under appropriate framing. Disagreements, even with deep ideological divides (e.g. on the role of government), are vital to democracy and have tended toward compromise and balanced solutions throughout America's history. Bitter partisanship and policymaking conflicts are not new, with historical precedents even from the nation's first decades that reflect through to present-day partisanship (Heineman Jr. 2011). Tensions between government policymakers became tempered through the traditions and norms of Constitutional democracy and bipartisan procedural governance, which generally held following contentious elections. In recent decades this changed with the descent into "take-no-prisoners" politics (Moss 2012; Levitsky and Ziblatt 2018).

The costly non-cooperative status-quo requires explanation, and many have been proposed. Appeals to reason, unity, and patriotism have done little to assuage the divisive general pattern and its growth, despite the high policymaking and social costs. We describe explanations in three complementary views of an increased cost-benefit ratio of cooperation, which we call: Unstable Asymmetric Zero-Sum (the payoff structure has become more asymmetric, and Republican leaders have adopted asymmetrically noncooperative initiatives), Party-Ideology Polarization, and Stag-Hunt Risk Avoidance.

\section{Unstable asymmetric zero-sum}

Non-cooperative outcomes have occurred more frequently due to more key participants treating this not as a repeated Prisoner's Dilemma (nonzero sum), but purely as a zerosum game centered around the election cycles, now reflected in nearly every policymaking choice. As relationships between leaders and the parties have become more adversarial, compromises - however rational and balanced - have tended to please no one from a political or policy perspective, making it very difficult to move compromise policies forward. ${ }^{5}$

Policymaking choices conditional on "winning" or "losing" elections change over time, as shown in Fig. 2. If Republicans in power can push through their desired policies without any Democratic ideas or votes, they generally don't need them, and they tend to view this as the best policy outcome for the country. Democrats conversely and symmetrically believe that policies implemented in the Democrats Win/Republicans Lose box are the best achievable, with no balance or votes needed from Republicans if that's what it takes while they are in power.

The "sucker" payoff is different, reflecting who is in power and by how much; it corresponds in each case to the "lose" outcome for the party not in power and the "lose gain" outcome for the party in power, but the principle is the same. ${ }^{6}$ Figure 2 also includes a "cooperate-cooperate" outcome that occurs at times on "smaller" or less contested policy matters-some compromises where bipartisan governance does continue to reasonably function.

\footnotetext{
5 This is an international problem also, of course, as in Britain's recent Brexit dilemmas.

6 The added dimension of which party is in power alters the nature of the strategy choices, but it still results in payoff outcomes for each that satisfy the worst outcome in the "lose" or "lose gain" (i.e., "sucker") "option.".
} 
Republicans in Power

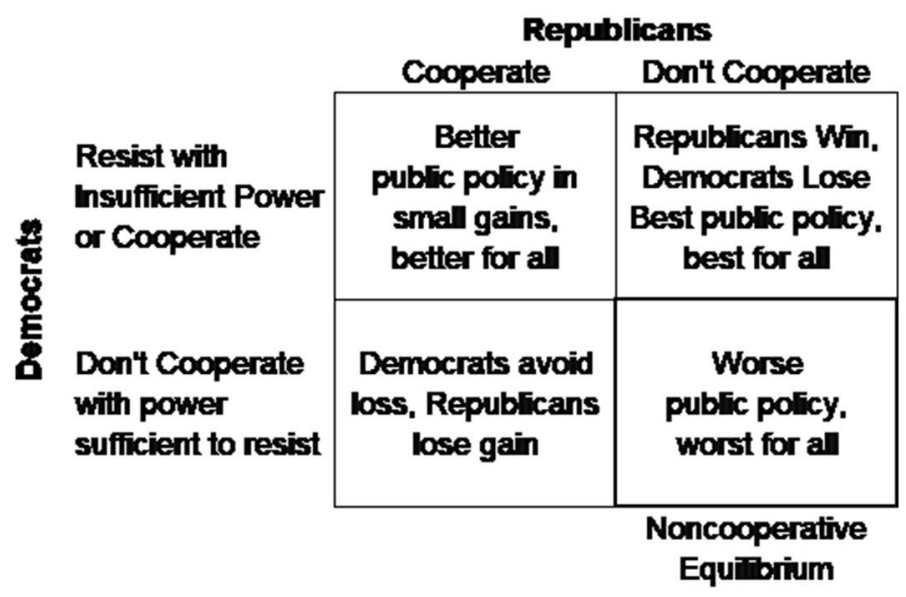

\section{Democrats in Power}

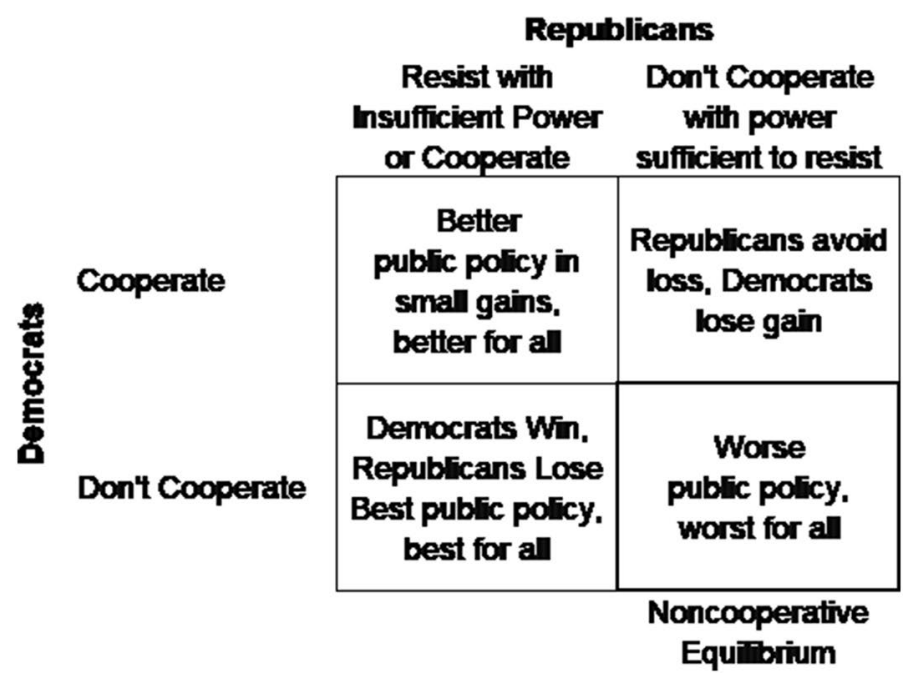

Fig. 2 Power-dependent policymaking choices and perceptions

The Prisoner's Dilemma payoff structure has become more asymmetric due to institutional, political, and societal changes, making the political policymaking process more like a zero-sum game, with higher incentives for "party domination."7 The prospect of election

\footnotetext{
7 Flood and Dersher conceived the original Prisoner's Dilemma game with an asymmetric payoff structure (Flood 1952; Poundstone 1992); one player received a relatively higher payoff in all outcomes except for the "sucker." The two original game participants played 100 times, and after a learning period, with some later defections requiring punishment, mutual cooperation was the most common albeit not dominant outcome
} 
victory for President or a Congressional majority offers the winner a considerable time for asymmetrically large payoffs from a dominant position. The growth over time of multiple policymaking powers concentrated in the "imperial presidency" and "executive federalism" has significantly enhanced the one-party-dominant policymaking potential gained through electoral victory of the Presidency (Schlesinger 1973; Modie and Curcy 2011; Friedersdorf 2016; Cost 2018; Head 2019a, b; Blow 2019; Thompson et al. 2018). Particularly when a party holds the White House and both houses of Congress with sufficient party loyalty in votes, the losing party's acquiescent "cooperation" on opposed policy matters is guaranteed as the losing party can only "resist with insufficient power," e.g. in the recent-years' focus on political appointments to the judiciary. ${ }^{8}$ The incidence of cooperation depends significantly on the game's parameters. More asymmetric payoffs lower the likelihood and frequency of cooperation making cooperation unstable and less sustained (Sheposh and Gallo 1973; Beckencamp et al. 2007; Ahn et al 2007). ${ }^{9}$

As the payoff structure has become more asymmetric, more combative non-cooperative strategies have emerged with political successes, further lowering cooperation. Non-stop strategizing for electoral gains polarizes not just elections but the many processes of governance and policymaking, with countervailing unilateral obstructions, tit-for-tat non-cooperation, and power-play policymaking. Repeated non-cooperation tends to follow any defection nearing the end of a finite game. Trump's nonstop campaigning from the time of taking of office, for example, has heightened the reframing of governance as a nearing-end finite game. The general observation that "little gets done in an election year" now extends to almost every year.

Obstructions and power-play policymaking have long been tactics used by both parties; however, Republican leaders, reflecting a larger extent of party polarization to the right (Hacker 2015; Thurber and Yoshinaka 2015) and other factors, have taken such "hardball" or "win at all costs" tactics to new heights in systematic initiatives for the past 25 years (Barr 2010; Lofgren 2011, 2012, Mann and Ornstein 2012; Grunwald 2012; Mann and Corrado 2014; Dionne et al. 2017; Atkins 2017; Coppin 2018; Levitsky and Ziblatt 2018; Hacker and Pierson 2005; Bai 2005). Before President Obama even took office in 2009, for example, Republican leaders planned to continue a combative uncompromising approach begun by Newt Gingrich's GOP-controlled House in the 1990s-not just to politically pursue a November 2010 change in the Congress, but to block nearly every policy proposal from the new White House, even an attempted "bipartisan" jobs bill in the depth of the Great Recession (Lofgren 2011, 2012; Coppin 2018). ${ }^{10}$ Before taking office in 2001 after a contested divisive election, President George W. Bush pledged to be a "uniter not a divider," but he was subsequently told by GOP House Majority Whip Tom DeLay (a

Footnote 7 (continued)

$(60 \%)$, contrary to the Nash prediction. The weaker party gained the most from the cooperation in the pattern that occurred.

${ }^{8}$ Other tactics in Congress and at the state level with gerrymandering strategies, etc. have been aggressively (and successfully) employed to enhance the prospects of longer-term overall one-party-dominant policymaking.

9 Unstable cooperation may also reflect other assumptions that have been challenged in IPD research and assessment, questioning the robustness of cooperative versus more ruthless strategies and raising doubts about the IPD as an explanation of cooperation in evolutionary outcomes, and questioning the usefulness of the Prisoner's Dilemma in empirical explanation (Northcott and Alexandrova 2015; Arnold 2013; Raihani and Bshary 2011; Linster 1992).

${ }^{10}$ No Republicans in the House and only three in the Senate ultimately voted for a watered-down fiscal stimulus despite the ongoing severe recession. This ruthless political-strategizing intertemporal choice became more public in 2010 with Mitch McConnell's proclamation to make Obama a one-term President and Republican pledges for "no compromise" (Barr 2010). 
Gingrich ally), "We don't work with Democrats. There'll be none of that uniter-divider stuff." Advised by Karl Rove, Bush largely abandoned bipartisanship and governed to satisfy the partisan right base, which was followed by tit-for-tat partisan Democratic Senate obstructions of Bush's judicial nominees (Levitsky and Ziblatt 2018). Such actions have marked or made more visible a significant shift in the traditional social contract in policymaking that encouraged or allowed more bipartisanship.

On the larger or more difficult policies or wherever strongly contested principles are involved, the party in power may choose procedural or effective non-cooperation (hold no hearings, no bipartisan fact finding, etc., or eventually proceed with unilateral preferences) in order to pass its most desired legislation using party-line votes. Periods in which the same party has managed to win the Presidency and both houses of Congress have been limited, and party uniformity is not always a given. Along with more modest bipartisan policy changes, only occasional enacted larger policy changes have escaped from legislative deadlock through unilaterally asserted power. Counter policies or reversals when the political power balance shifts - as exemplified in the extreme by Trump's reversals and undercutting of so many Obama-era policies-result in non-cooperative deadlock in the longer term with whipsawing changes making it very difficult for longer-term public and private planners.

Policymaking in this repeated zero-sum context has resulted in polarized governance with a need for power-play policymaking to accomplish any major change or even basic governing functions. ${ }^{11}$ Mann and Corrado (2014) discuss the poor match of extreme polarization with the American constitutional system and separation of powers with constraints on majority rule. Non-cooperative GOP behavior persisted through Obama's two presidential terms (compromises came close to passage in Congress but could not move beyond obstructions from Republican factions), leading to tit-for-tat presidential and Democratic behavior. The general state of non-cooperative policy deadlocks and power plays has only grown through the Trump years. GOP-leader "successes" in obstructions and power-play policy changes have evolved the current GOP-leadership strategy into refusing to allow Democratic party leaders to effectively govern after they are elected, while waiting to aggressively pursue a power shift back to the GOP for pursing GOP-preferred policies. Such "achievements" reinforce the asymmetry of the perceived payoff structure, with stronger incentives to obtain the dominant power-play policymaking position. ${ }^{12}$

Many Republicans, in addition to most Democrats, have found the candidacy and presidency of Donald Trump "distasteful” at least, repulsive, or unacceptable (at least privately) in its incivility, divorce from facts, policymaking incompetence, and authoritarian extremism. In many ways, however, Trump's tactics have been a grotesquely logical extension of

\footnotetext{
11 The minority or non-dominant party can still have influence, where allowed, for example through legislative amendments (Krehbiel et al. 2015).

12 The origins of the party-based asymmetry in policymaking behavior may reflect, for example: (1) GOP antipathy to "big government" (except for military spending) with a ruthless calculus that government dysfunction benefits Republican as opposed to Democratic policy preferences (Lofgren 2011); (2) policy problems creating more demands for government action, which Republicans generally prefer to oppose; (3) differences in personality-type and civics across the parties (including the styles of party leaders), e.g. more judging assertive or persistent types among Republicans or conservatives and more agreeableness among those with left-wing orientation (Drenth 2008; Darrell 2016; Furnham and Fenton-O'Creevy 2018); Allgood et al (2010) found economics majors more likely to be Republicans, while in Prisoner's-Dilemma experiments Frank, et al (1993) found that studying economics as an undergrad may inhibit cooperation; (4) GOP party leaders anxious to "leave their mark" on history; and (5) long-term urbanization, industrial shifts, and changing demographics and societal practices that have typically aligned more with the Democratic party, threatening traditional Republican societal preferences and comfort with the past.
} 
combative noncooperative strategies. The continued support of the GOP party structure in addition to Trumpian loyalists reveals both the strength of Republican leaders' "win at all costs" policymaking resolve and the depths of "us-versus-them" party ideology.

\section{Party-ideology polarization}

Despite posturing about the needs for bipartisanship to address unmet policy needs, the incentives for party loyalty and adherence to party ideology add significantly to partisans' incentives to "win" uncompromisingly on policy views (Thurber and Yoshinaka 2015). The group behavior has ideological or identity driven battle-promoting characteristics that differ from a simple sum of individuals. The need to belong, affiliate, reinforce, and elevate one's group is a strong psychological motivation (Baumeister and Leary 1995). Social identities and the biology of groups (Hornung et al. 2018; Forsyth 2019) incline policymakers toward conformity with party policy views, party loyalty, party-affiliated campaign themes and public expressions, and party-line voting (Bernheim 1994; Cialdini and Goldstein 2004; Berns et al 2005; Yu and Sun 2013; Close 2016; Harell 2018; Cherry 2019). Financial incentives in party-driven or inspired fundraising and ideological views within parties add strong practical constraints against centrist moderation (Mann and Corrado 2014; O’Donnell 2016; Gehl and Porter 2017; Tomasky 2019a). Penalties for non-conformity make it difficult for Independent candidates to compete. Perceived needs to satisfy the "party base" to stay in power push political decision-makers to conform even where it contradicts a policymaker's principles.

In this type of explanation, consistent with the first, polarization has reframed most policymaking discourse not around policy substance and tradeoffs but as a zero-sum game, with whatever policy gains or changes the left (right) achieves characterized as losses of the right (left) (Easley et al. 2015). Polarized identities with intolerance of "others," mistrust, and lowered willingness to negotiate and compromise over opposing policy viewpoints have grown, as have more extreme and caustically expressed political views, elevated by accommodative media coverage of policymaking fights or "battles." Trends of politicized evidence and willful ignorance (Perl et al. 2018; Paul and Haddad 2019) have helped to fuel negative partisan views of the "other side" with their "bad people" and "dangerous ideas" (Theodoridis 2016; Hetherington and Rudolph 2015), strangely inventive conspiracy theories, and partisan denials and disagreements on simple facts (Dunning 2016). Low turnout in party primaries and ideologically driven voters have advantaged more extremist candidates with a limited but more mobilized base of support, resulting in a hollowing out of lawmakers with more centrist views in Congress (Wheelan 2013; Gehl and Porter 2017; Mann and Ornstein 2012). Many potential improvements in policy today have effectively become held hostage to the extremes of both parties and a stifled competition of ideas for more creative balanced policy solutions (Alberta 2018; Brooks 2018a, b, 2019). The Trumpian presidential approach has joined with the other previous and ongoing strands of non-cooperative GOP power assertion to further deepen the political divides and loss of trust in policymaking discourse, often justified through odd concoctions from right-wing media, fueling outrage on the left, and leaving a steady barrage of negative partisanship and "our story versus theirs" portrayals.

Over a decade ago, psychologists pointed to the importance of prominent repeated divisive communications in simplistic characterizations like "red and blue states," arguing this would exacerbate social divisions (Seyle and Newman 2006). ${ }^{13}$ Words, and especially repeated

13 A simple alternative to "red and blue" was suggested but has almost never been followed. 
divisive words, matter, a factor central to Trump's political messages and methods. The confluence of technology, media, social, business, political, and communication factors can now be described as a "perfect storm" amplifying today's political divisions (Evans 2018). Partisan media feeding, and feeding on, conflict has grown into a big business now symbiotically and ominously aligned on one side with Trump's political interests (Avlon 2019).

Conformity has been found to lower perceptions of the truth (Asch 1951, 1952, 1956; Berns et al 2005) and increase polarization in attitudes (Moscovici and Zavalloni 1969). ${ }^{14}$ Neuro-cognitive inclinations and a more uncertain environment incline individuals toward a greater extent of views and decisions conforming with the common behavior of the group (Henderson 2017; Fox 2008; Grene 2011). Many voters may care more about their social identities than the particulars of any ideology, affecting coalitional views within both parties (Bacon Jr. 2019). A more uncertain environment may also tend to incline individuals toward preferring a dominant leader, even a polarizing one (Kakkar and Sivanathan 2017).

Kavanagh and Rich (2018) concluded that, compared with earlier historical periods of "truth decay" (the 1880s-1990s, 1920s-1930s, and 1960s-1970s), the last two decades have seen a similar blurring between opinion and fact, and similar growth and influence of opinion, but a deeper loss of confidence in major institutions, and more disagreement about facts and interpretations. With Orwellian lies and counterattacks now regularly assaulting facts, truth, and the mainstream media from the highest office today (Sunstein 2019; Dayen 2019; Goddard 2019; Leonhardt et al 2017), authoritarian tendencies have ominously grown (e.g. Stenner 2005; Lofgren 2013; Taub 2016; Pettigrew 2017; Ongstad 2019). ${ }^{15}$

In the excesses of the Trump era, the marks of authoritarianism with power-play policymaking have become clear. ${ }^{16}$ Enough votes against mainstream candidates empowered through the primaries and electoral college a new type of president even though he was viewed by many as a "deeply flawed and clearly unfit demagogue" (Dionne et al. 2017). ${ }^{17}$ Unlike past presidents, apart from occasional speeches scripted by others, Trump has made no attempt and shown no capacity for uniting the country or actually "making policy deals," but instead has become a Twitter-message divider in chief. Nonetheless, he has retained strong percentage support within the Republican base-although this firm base is not a particularly large share of all Americans. ${ }^{18}$ Past American demagogues such as

\footnotetext{
14 A striking example occurred in the opposed public views of Republican and Democratic leaders concerning Trump's multiple actions in the Ukranian arms-for-investigations-of-opponents shakedown culminating in his remaining in office despite impeachment.

15 Stretched political and policy-outcome narratives have long played out in political "spin," especially during election years. In recent years, however, negative partisanship has dominated partisan media and policymaking practice, leading to Trump's unprecedented falsehoods and obfuscation of facts.

16 Authoritarian tendencies are not just a U.S. phenomenon, as recent events in Britain have shown, for example, with Boris Johnson's move seeking to suspend Parliament at the critical September-October 2019 Brexit juncture.

17 Protest voting against mainstream politicians has continued to emerge in many other countries as well.

18 Self-reported Republicans and Democrats have become minority groups in Gallup polling, hovering generally around $25-27 \%$ for Republicans, and $27-32 \%$ for Democrats. Problems from the Iraq war, the financial crisis, other policy-related problems, and policy gridlock have been significant factors taking down the percentages of self-reported Republicans since 2005, and the percentages identifying as affiliated with either party. Since 2005 and especially since 2010, self-reported Independents have clearly become the largest, hovering in recent years generally between 37 and 45\%, reflecting dissatisfaction with the two parties or party leaders. With Independents asked how they "lean," toward Democrat or Republican, added in, a tendency toward party conformity is much higher, in recent years around 45-50\% toward the Democratic party and about $40-45 \%$ toward Republican. These totals may be inflated by the nature of the Gallup question (only two choices), however, and even the sum of these two totals has declined over time from about $90-95 \%$ to $85-90 \%$.
} 
Huey Long in the 1930s and George Wallace in the 1960s were effectively screened by party gatekeepers, but traditional party "guardrails" against demagogic autocratic extremism have failed to contain Trump (Levitsky and Ziblatt 2018). GOP tolerance of Trump has reflected "ideological collusion" (Ermakoff 2008) through sufficient overlap with the mainstream GOP's agenda. ${ }^{19}$

Policy deadlock through stalemates and alternating parties in power has become widely recognized, but "winner take all" strategies for party dominance coupled with "illusory superiority bias" (Ghose 2013) may cause "predictably irrational" expectational and confirmation biases (Ariely 2008; Jerit and Barabas 2012; Wason 1960) with leaders from both parties believing that they can, should and will win more policy changes through successive elections than they actually do win over time. A condition of a Prisoner's Dilemma may be violated - that the players should not find it better to "take turns" exploiting each other. The payoff for mutual cooperation should be greater than the approximate average of the payoff for the temptation and sucker (Chong et al. 2007, chp. 1). This condition is not satisfied if party leaders generally believe that, in a more-or-less alternating sequence, they can achieve more in power, and later lose less out of power. Other cognitive biases conditioned by party loyalty may create 'noise' that interrupts behavioral signals of reciprocating cooperation and further lowers perceptions of potential routes to balance and compromise (Jerit and Barabas 2012; Wason 1960; Molander 1985).

By many measures, polarization has increased over time (Boxell et al. 2017), and it may be significantly more concentrated within the political leadership than in the public at large (Stein 2016). Training and traditions in the law and legal representations have taught many policymakers to think in terms of zealous advocacy for the "client" (in this case, the party's policy position) and a zero-sum win-or-lose game. Another reason for such concentrated polarization may reflect the basic neuropsychological need for party leaders to respond most, and answer to their more extreme party wings and dogmatic adherents (Zmigrod 2019) when most mobilized, by cases of identified versus statistical lives (Cohen et al. 2015) - a key reason why political campaigns highlight identified-life cases rather than dry statistical policy tradeoffs. With concentrated leadership polarization, so long as partisan warfare continues, policymaking leaders may feel largely compelled to endlessly seek "zero-sum" dominance or the upper hand rather than striving for more productive bipartisan balance and compromise- even as the public continues to lose trust in this policymaking process.

\footnotetext{
${ }^{19}$ Feldman and Stenner (1997) and Stenner (2005), for example, describe the associated personality traits of a predisposition toward authoritarianism. Rauch (2016) similarly describes 'politiphobes' who believe that meaningful policy disagreements don't even exist and obvious policy solutions (the sorts they prefer) are not enacted because politicians are corrupt, self-interested, or addicted to unnecessary partisan feuding. Hetherington and Weiler (2009), MacWilliams (2016), Taub (2016) and Jacobs (2018), for example, have described the associated factors as the rise of American authoritarianism, rooted in psychological tendencies desiring order and fearing outsiders or normative threat. Pettigrew (2017) describes the corresponding and related social psychological perspectives on Trump supporters, and Ongstad (2019) describes Trump's brand of uniquely "American authoritarian" actions. Trump's brazenly asking for supportive election meddling by foreign governments and apparently "getting away with it" further encourages the GOP's "win at any cost" partisan beliefs and behavior and incents Democratic leaders and strategists to respond with noncooperation.
} 


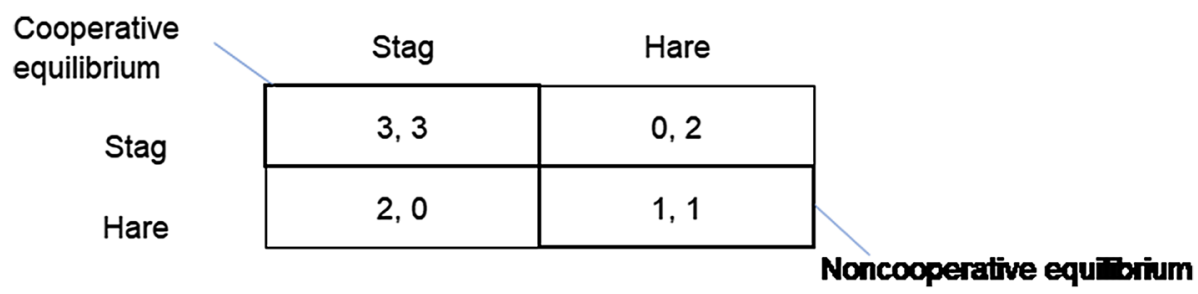

Fig. 3 Stag Hunt game

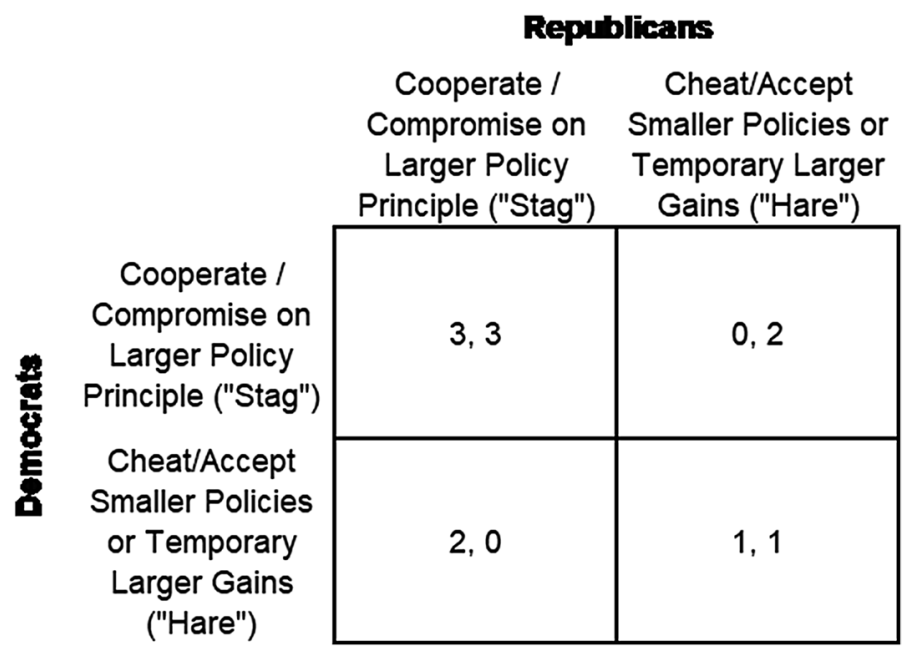

Fig. 4 Policymaking choices as a Stag Hunt

\section{Stag-Hunt risk-avoidance}

Political policymaking can alternatively be viewed as a Stag Hunt game, as illustrated in Figs. 3 and 4. In a group of hunters waiting quietly for the larger prize of stags, each hunter is incented individually to go after the hare, to obtain something to eat sooner and at lower risk, but also spoiling the Stag Hunt. In the non-cooperative Nash equilibrium, the hunters subsist on rabbits, but they miss out on the 6 stags for all to share ( 3 each). This is an individually optimal but socially suboptimal state of nature, calling for a social contract.

Likewise, Democrats and Republicans do not know if or when the serious possibility of larger, meaningful, but very difficult progress on cooperation and compromise between their divergent policy preferences might show up in any particular large but neglected or problematic policy area, allowing more productive and lasting policy solutions, or if such possibility will ever truly appear. There is both a highly productive cooperative equilibrium $(3,3)$, and a much less productive non-cooperative equilibrium $(1,1)$.

Unlike the Prisoner's Dilemma, where the individual party's self-interest best outcome at each move is always in the defect or cheat strategy attempting to try to exploit the other party, in the Stag Hunt each party leader should tend to recognize that they may ultimately 
obtain an even larger payoff not just for the collective but for themselves individually over time if they can only somehow agree on cooperation that is enforceable. The best responses for each party leader are clearly to cooperate in response to cooperation, and cheat or defect in response to cheating. After recurring rounds of cheating (and alleged cheating) to try to exploit the other party (with the 0,2 or 2,0 payoff temporarily), however, each side finds that the non-cooperative equilibrium generally prevails with the illustrative $(1,1)$ average payoffs for each party in the non-cooperative equilibrium. The better larger policy solutions from the alternative cooperative equilibrium remain largely unobtainable.

Mutual cooperation is an alternative Nash equilibrium due to its potential larger gains for all. Republican and Democratic policymakers find this unobtainable, however, because they are risk averse and have become increasingly uncertain about the prospects for larger, meaningful, but very difficult progress on cooperation and compromise between their divergent policy views. Even where risk aversion is lower, due to ambiguity effects policymakers avoid more prolonged negotiating choices with ambiguous or unknown outcomes (Frisch and Baron 1988). Untrustworthy and mercurial negotiating tactics, such as exhibited repeatedly by Trump in Congressional dealings, further forestall any cooperative policymaking progress. Cooperative outcomes are "payoff dominant," but non-cooperative outcomes are "risk dominant" (Harsanyi and Selten 1988). Non-cooperation dominates by being the safer option (Golman and Page 2010). Without a reasonably successful social contract to encourage or enforce greater cooperation (Skyrms 2001, 2004), cooperative policy outcomes are persistently thwarted, especially on larger or more difficult issues. ${ }^{20}$

The traditional social contract, following partisan elections, encouraged more cooperation through bipartisan problem-solving and negotiation traditions and procedures in governance (Foran 2018; Rauch 2016; Moss 2012; Levitsky and Ziblatt 2018) —as resulted, for example, in the Reagan-O’Neill Social Security Deal of 1983 (Dallek 2009). Although the Stag Hunt view allows for a stable equilibrium of policymaking cooperation, it does not solve the problem of cooperation since there is also the non-cooperative equilibrium (Skyrms 2004). A cooperative equilibrium requires that enough policymakers from both parties somehow agree to negotiate in good faith, agree to compromise, and agree to "hunt" the larger more lasting bipartisan policy improvements through consistent mutually practiced cooperation. ${ }^{21}$

\footnotetext{
${ }^{20}$ Learning is a complex topic in game theory social dilemmas, and fear of a greater loss in the "sucker" payoff may have risk aversion effects primarily through fear of large losses (Macy and Flache 2002; Izquierdo et al 2008). The avoided risks of cooperation may be less in the costs of thwarted policy gains and more in fear of larger "sucker" payoffs from compromise allowing policy changes that cannot later be undone, or from future electoral loss. This is a rational response to actual, perceived, or claimed partisan or extremist exercises of power. "Win at all costs" non-cooperative partisanship as a strategy makes opposing party leaders ever more risk averse against loss, ever more inclined to avoid compromise. Re-establishing trust between party leaders becomes increasingly difficult.

${ }^{21}$ IPD research by Press and Dyson (2012a, b), as described in Edge.org (2012), implies that opposing players can maximize their mutual scores through a cooperative "treaty." Cooperate versus defect in political dysfunction can be viewed as "peace or war." Agreeing to compromise also requires a sense of humility on policy views and willingness to work very hard to reach acceptable tradeoffs, despite many unpredictable challenges.
} 


\section{Conclusion}

The complementary explanations described above imply that despite the high and growing social costs, the non-cooperative policymaking equilibrium has become self-reinforcing within and across the opposing party groups psychologically, politically, and financially (e.g. Turner 2010; Hornung et al. 2019; Gehl and Porter 2017; Levitsky and Ziblatt 2018). It cannot be assumed that leaders simply acting rationally rather than emotionally will solve this problem - the problem is fundamentally a failure of rationality under the current conditions.

The limits of rationality do not end with an intractable Prisoner's Dilemma, however, as suggested by the Stag Hunt view, which is an important conceptual shift. In the Prisoner's Dilemma, policy beliefs and incentives to "win" tend toward every actor defecting, and a winner-take-all mentality, while a re-establishment of cooperation requires a success of higher-order strategies, such as tit-for-tat or alternatives (Axelrod 1984; $\mathrm{Wu}$ and Axelrod 1995), which may not be possible or sustainable. In the Stag Hunt, players are incented to cooperate provided that enough others do so as well. The choice to not cooperate is clearly sub-optimal for all in the long run, with usually only shortterm gains, even though it dominates by being the safer option. Party partisans differ of course on the large non-cooperative policy battles in recent years, but few can deny the sad state of overall affairs, as reflected on by departing Senators in 2018 (Foran 2018). Social suboptimality persists fundamentally because of the perceived high risk-adjusted cost-benefit ratio of cooperation.

This implies that institutional changes to promote cooperation should focus on overcoming its risks, i.e. lowering the risk-adjusted cost-benefit ratio, making cooperation safer and more attractive for policymakers. New institutional conditions to encourage more trust and fewer divergent incentives in key political relationships, which can lower the perceived cost and raise the perceived benefit, are needed for greater policymaking cooperation to become individually rational for each party leader. The proposed new presidential administration with bipartisan leadership inclusion in policymaking takes this approach. Reframing the partisan divides in this way would seek to counter negative partisanship and extremes, reestablish better policymaking interactions and improve governance and policy outcomes.

\section{References}

Ahn, T. K., Lee, M., Ruttan, L., \& Walker, J. (2007). Asymmetric payoffs in simultaneous and sequential Prisoner's Dilemma games. Public Choice, 2007(132), 353-366. https://doi.org/10.1007/s1112 7-007-9158-9.

Alberta, T. (2018). 'Americans are being held hostage and terrorized by the fringes.' An exit interview with the American Enterprise Institute's Arthur Brooks. POLITICO Magazine. Retrieved June 27, 2019 from https://politi.co/2rEUMOd.

Allgood, S., Bosshardt, W., van der Klaauw, W., \& Watts, M. (2010). Is economics coursework, or majoring in economics, associated with different civic behaviors? Federal Reserve Bank of New York Staff Reports, no. 450.

Ariely, D. (2008). Predictably irrational: The hidden forces that shape our decisions. HarperCollins Publishers.

Arnold, E. (2013). Simulation models of the evolution of cooperation as proofs of logical possibilities. How useful are they? Etica \& Politica/Ethics \& Politics, XV(2), 101-138.

Asch, S. E. (1951). Effects of group pressure upon the modification and distortion of judgment. In H. Guetzkow (Ed.), Groups, leadership and men. Pittsburgh, PA: Carnegie Press. 
Asch, S. E. (Ed.). (1952). Group forces in the modification and distortion of judgments. In Social psychology (pp. 450-501). Prentice-Hall, Inc.

Asch, S. E. (1956). Studies of independence and conformity: I. A minority of one against a unanimous majority. Psychological Monographs: General and Applied, 70(9), 1-70.

Atkins, D. (2017). The Prisoner's Dilemma: Why democrats should block Gorsuch. The American Prospect. Retrieved June 1, 2019 from https://prospect.org/article/prisoner\%E2\%80\%99s-dilemmawhy-democrats-should-block-gorsuch.

Avlon, J. (2019). Confronting the cult of partisan media. CNN opinion. Retrieved July 2, 2019 from https ://www.cnn.com/2019/11/22/opinions/partisan-media-confronting-political-division-avlon/index .html.

Axelrod, R., \& Dion, D. (1988). The further evolution of cooperation. Science, New Series, 242(4884), $1385-1390$.

Axelrod, R., \& Hamilton, W. D. (1981). The evolution of cooperation. Science, 211(4489), 1390-1396.

Axelrod, R. M. (1984). The evolution of cooperation (rev ed.). New York, NY: Basic Books.

Axelrod, T. (2019). The House-passed bills that have ended up in the Senate 'graveyard'. The Hill. Retrieved July 2, 2019 from https://thehill.com/homenews/senate/449780-a-list-of-the-democratic -legislative-priorities-being-held-up-in-the-senate.

Bacon Jr., P. (2019). What unites Republicans may be changing. Same with democrats. fivethiryeight. com. Retrieved December 21, 2109 from https://fivethirtyeight.com/features/what-unites-repub licans-may-be-changing-same-with-democrats/?utm_source=pocket-newtab.

Bai, M. (2005). The excluded middle. New York Times Book Review.

Barr, A. (2010). The GOP's no-compromise pledge. Politico. Retrieved June 1, 2019 from https://www. politico.com/story/2010/10/the-gops-no-compromise-pledge-044311.

Bauman, B. (2018). Trapped in a prisoner's dilemma. Retrieved May 25, 2019, from Banyan Hill Publishing website https://banyanhill.com/political-hypocrisy/.

Baumeister, R. F., \& Leary, M. R. (1995). The need to belong: Desire for interpersonal attachments as a fundamental human motivation. Psychological Bulletin, 117(3), 497-529. https://doi. org/10.1037/0033-2909.117.3.497.

Beckencamp, M., Hennig-Schmidt, H., \& Maier-Rigaud, F. P. (2007). Cooperation in symmetric and asymmetric prisoner's dilemma games. Bonn: Max Planck Institute for Research on Collective Goods.

Bernheim, B. D. (1994). A theory of conformity. Journal of Political Economy, 102(5), 841-877.

Berns, G. S., Chappelow, J., Zink, C. F., Pagnoni, G., Martin-Skurski, M. E., et al. (2005). Neurobiological correlates of social conformity and independence during mental rotation. Biological Psychiatry, 58, 245-253.

Blow, C. M. (2019). An imperial presidency? The New York Times. Retrieved June 1, 2019 from https:// www.nytimes.com/2019/05/12/opinion/trump-imperial-presidency.html.

Bowden, J. (2019). Most NH voters would back "unity ticket" in 2020: Poll. The Hill. Retrieved February 2, 2019 from https://thehill.com/homenews/campaign-polls/425788-most-nh-voters-suppo rt-unity-ticket-in-2020-poll.

Boxell, L., Gentzkow, M., \& Shapiro, J. M. (2017). Greater internet use is not associated with faster growth in political polarization among US demographic groups. PNAS, 114(40), 10612-10617. https://doi.org/10.1073/pnas.1706588114.

Brooks, A. C. (2018a). Arthur brooks to step down as president of AEI. Retrieved February 2, 2019 from https://www.npr.org/2018/05/15/611199663/arthur-brooks-head-of-american-enterprise-insti tute-to-step-down.

Brooks, A. C. (2019). Love your enemies: How decent people can save America from the culture of contempt. New York: Broadside Books/Harper Collins.

Brooks, D. (2018b). Opinion. The retrenchment election. The New York Times. Retrieved February 2, 2109 from https://www.nytimes.com/2018/11/01/opinion/2018-midterms-realignment-partisansh ip.html.

Chantrill, C. (2013). President Obama and the Prisoner's Dilemma. Retrieved June 11, 2019, from American Thinker website https://www.americanthinker.com/articles/2013/01/president_obama _and_the_prisoners_dilemma.html.

Cherry, K. (2019). How does conformity influence behavior? verywellmind.com. Retrieved November 17, 2019 from https://www.verywellmind.com/what-is-conformity-2795889.

Chong, S. Y., Humble, J., Kendall, G., Li, J., \& Yao, X. (2007). The iterated Prisoner's Dilemma: 20 years on. In G. Kendall, et al. (Eds.), The iterated Prisoners' Dilemma: 20 years on. World Scientific Books, World Scientific Publishing Co. Pte. Ltd. 
Cialdini, R. B., \& Goldstein, N. J. (2004). Social influence: compliance and conformity. Annual Review of Psychology, 55(1), 591-621. https://doi.org/10.1146/annurev.psych.55.090902.142015.

Close, C. (2016). Rethinking intra-party cohesion. Paper presented at Australian Political Studies Association Annual (APSA) Conference. Retrieved June 8, 2019 from https://www.researchgate.net/ publication/308412861_Rethinking_intra-party_cohesion.

Cohen, I. G., Daniels, N., \& Eyal, N. (Eds.). (2015). Identified versus statistical lives: An interdisciplinary perspective. Oxford: Oxford University Press.

Contrisciani, J. (2018). Our politics are a failed Prisoner's Dilemma. Retrieved May 25, 2019, from https ://jennicontrisciani.wordpress.com/2018/02/10/our-politics-are-a-failed-prisoners-dilemma/.

Coppin, M. (2018). The man who broke politics. The Atlantic. Retrieved October 2, 2019 from https:// www.theatlantic.com/magazine/archive/2018/11/newt-gingrich-says-youre-welcome/570832/.

Cost, J. (2018). Donald Trump and the imperial presidency. National Review. Retrieved July 1, 2019 from https://www.nationalreview.com/2018/12/donald-trump-modern-imperial-presidency/

Curry, J., \& Lee, F. (2019). Non-party government: Bipartisan lawmaking and party power in congress. Perspectives on Politics, 17(1), 47-65. https://doi.org/10.1017/S1537592718002128.

Dallek, M. (2009). Bipartisan Reagan-O'Neill Social Security deal in 1983 showed it can be done. U.S. News \& World Report. Retrieved May 11, 2019 from https://www.usnews.com/opinion/artic les/2009/04/02/bipartisan-reagan-oneill-social-security-deal-in-1983-showed-it-can-be-done.

Darrell. (2016). The U.S. political personality (I): Parties. 16personalities.com. Retrieved July 2, 2019 from https://www.16personalities.com/articles/the-us-political-personality-i-parties.

Dayen, D. (2019). Nothing Trump said was true. The Atlantic. Retrieved June 9, 2019 from https://www. theatlantic.com/ideas/archive/2019/04/trump-organizations-dishonesty-all-too-common/586366/.

Derwort, P., Jager, N., \& Newig, J. (2018). Towards productive functions? A systematic review of institutional failure, its causes and consequences. Policy Sciences, 52(2), 281-298.

Desai, S. (2017). The Senator's Dilemma: Game theory, Gorsuch, and the nuclear option. Harvard Political Review. Retrieved May 25, 2019, from https://harvardpolitics.com/united-states/senators-dilemmagame-theory-gorsuch-nuclear-option/.

Dionne, E. J., Ornstein, N., \& Mann, T. (2017). One nation after Trump: A guide for the perplexed, the disillusioned, the desperate, and the not-yet deported. St. Martin's Griffin. ISBN 978-1-250-29363-3.

Drenth, A. J. (2008). Personality in politics: Liberals, conservatives, myers-briggs, \& the big five. Personalityjunkie.com. Retrieved July 3, 2019 from https://personalityjunkie.com/08/personality-politics-liber als-conservatives-myers-briggs-big-five/.

Dunning, D. (2016). Psychology shows that Democrats and Republicans can't even agree on objective reality. Quartz. Retrieved July 3, 2019 from https://qz.com/823183/republicans-and-democrats-cantagree-on-the-facts/.

Easley, D., et al. (2015). The prisoners' dilemma of modern American politics. Multiple-course blog. Cornell University. Retrieved January 5, 2019 from https://blogs.cornell.edu/info2040/2015/09/17/theprisoners-dilemma-of-modern-american-politics/.

Ermakoff, I. (2008). Ruling oneself out: A theory of collective abdications. Durham: Duke University Press.

Evans, D. (2018). Divided America: How did we end up here? Psychology Today. Retrieved July 1, 2019 from https://www.psychologytoday.com/blog/can-t-we-all-just-get-along/201812/divided-ameri ca-how-did-we-end-here.

Feldman, S., \& Stenner, K. (1997). Perceived threat and authoritarianism. Political Psychology, 18(4), $741-770$.

Flood, M. M. (1952). Some experimental games. Research Memorandum RM-789, RAND Corporation, June.

Foran, C. (2018). Departing senators warn: There's a problem with the current state of politics. CNN. Retrieved December 31, 2018 from https://www.cnn.com/2018/12/29/politics/departing-senatorssenate-retirements-advice-congress/index.html.

Forsyth, D. (2019). The psychology of groups. Retrieved June 10, 2019, from https://nobaproject.com/modul es/the-psychology-of-groups.

Fox, M. (2008). Herd mentality rules in financial crisis. Reuters.con. Retrieved July 2, 2019 from https ://www.reuters.com/article/us-financial-psychology/herd-mentality-rules-in-financial-crisis-idUST RE48T4VC20080930.

Frank, R. H., Gilovich, T., \& Regan, D. T. (1993). Does studying economics inhibit cooperation? Journal of Economic Perspectives, 7(2), 159-171. https://doi.org/10.1257/jep.7.2.159.

Freedman, M. (2019). David Brooks on the importance of connection. Washington Post. Retrieved July 4, 2019 from https://www.washingtonpost.com/outlook/david-brooks-on-the-importance-of-connection -in-life-and-society/2019/04/19/8221f5e8-54a2-11e9-814f-e2f46684196e_story.html. 
Friedersdorf, C. (2016). End the imperial presidency before it's too late. The Atlantic. Retrieved July 1 from https:/www.theatlantic.com/politics/archive/2016/05/donald-trump-is-coming/483578/.

Frisch, D., \& Baron, J. (1988). Ambiguity and rationality. Journal of Behavioral Decision Making, 1(3), 149-157. https://doi.org/10.1002/bdm.3960010303.

Furnham, A., \& Fenton-O'Creevy, M. (2018). Personality and political orientation. Personality and Individual Differences, 129(15), 88-91.

Gallup. Party Affiliation. (2019). Retrieved June 10, 2019, from Gallup website https://news.gallup.com/ poll/15370/party-affiliation.aspx.

Gammon, D. (2019). "Prisoner's Dilemma" could offer future shutdown solution. The Post and Courier. Retrieved April 20, 2019 from https:/www.postandcourier.com/opinion/commentary/prisoners-dilemma-could-offer-future-shutdown-solution/article_8ca15c54-233b-11e9-bd66-6bcbbf4a52 17.html.

Gehl, K. M., \& Porter, M. E. (2017). Why competition in the politics industry is failing America: A strategy for reinvigorating our democracy. Boston: Harvard Business School.

Ghose, T. (2013). Why we're all above average. Live Science. Retrieved July 28, 209 from https://www. livescience.com/26914-why-we-are-all-above-average.html.

Glover, J. (2018). Biden should run on a unity ticket with Romney. POLITICO Magazine. Retrieved February 3, 2019 from https://politi.co/2ruYqdN.

Goddard, T. (2019). Trump's dishonesty is not normal. Retrieved June 4, 2019, from Political Wire website https://politicalwire.com/2019/04/30/trumps-dishonesty-is-not-normal/.

Golman, R., \& Page, S. (2010). Individual and cultural learning in stag hunt games with multiple actions. Journal of Economic Behavior \& Organization, 73, 359-376. https://doi.org/10.1016/j. jebo.2009.11.005.

Grene, S. (2011). Uncertain investors follow the crowd. Financial Times. Retrieved July 21, 2019 from https://www.ft.com/content/a5fff770-dae9-11e0-a58b-00144feabdc0.

Grunwald, M. (2012). The party of no: New details on the GOP plot to obstruct Obama. Time. Retrieved June 2, 2019 from https://swampland.time.com/2012/08/23/the-party-of-no-new-details-on-thegop-plot-to-obstruct-obama/.

Hacker, J. (2015). Confronting asymmetric polarization. In N. Persily (Ed.), Solutions to polarization. New York: Cambridge Press.

Hacker, J., \& Pierson, P. (2005). Off center: The Republican revolution and the erosion of American democracy. New Haven: Yale University Press.

Hallsworth, M., \& Egan, M. (2018). Why governments need to nudge themselves. Retrieved March 9, 2019, from Behavioral Scientist website https://behavioralscientist.org/why-governments-need-tonudge-themselves/.

Harell, T. (2018). What is conformity psychology and what does it do to a person? betterhelp.com. Retrieved July 2, 2019 from https://www.betterhelp.com/advice/psychologists/what-is-conformity -psychology-and-what-does-it-do-to-a-person/.

Harsanyi, J., \& Selten, R. (1988). A general theory of equilibrium selection in games. Cambridge: MIT Press. ISBN 0-262-08173-3.

Hartle, T. (2019). 'Love Your Enemies' urges readers to meet vitriol with decency. Christian Science Monitor. Retrieved May 21, 2019 from https://www.csmonitor.com/Books/Book-Revie ws/2019/0411/Love-Your-Enemies-urges-readers-to-meet-vitriol-with-decency.

Haynes, D. D. (2018). Bridging the red and blue divide: Despite the rhetoric, it can still be done. Here's how. Milwaukee Journal Sentinel. Retreived July 2, 2019 from https://www.jsonline.com/story/ opinion/columnists/david-haynes/2018/11/15/smart-tactics-helping-bridge-americas-red-andblue-divide/2008065002/.

Head, T. (2019a). History of the imperial presidency. Thoughtco.com. Retreived October 27, 2019 from https://www.thoughtco.com/history-of-the-imperial-presidency-721446.

Head, T. (2019b). Unitary executive theory and the imperial presidency. Thoughtco.com. Retreived October 27, 2019 from https://www.thoughtco.com/unitary-executive-theory-the-imperial-presi dency-721716.

Heineman Jr., B. W. (2011). The origins of today's bitter partisanship: The founding fathers. The Atlantic. Retrieved August 4, 2019 from https://www.theatlantic.com/national/archive/2011/09/the-origi ns-of-todays-bitter-partisanship-the-founding-fathers/244839/.

Henderson, R. (2017). The science behind why people follow the crowd. Psychology Today. Retrieved July 2, 2019 from https://www.psychologytoday.com/us/blog/after-service/201705/the-sciencebehind-why-people-follow-the-crowd.

Henriques, G. (2017). Our divided America. Psychology Today. Retrieved April 28, 2019 from https:// www.psychologytoday.com/us/blog/theory-knowledge/201712/our-divided-america. 
Hetherington, M. J., \& Rudolph, T. J. (2015). Why Washington won't work: Polarization, political trust, and the governing crisis. Chicago Studies in American Politics, The University of Chicago Press.

Hetherington, M. J., \& Weiler, J. D. (2009). Authoritarianism and polarization in American politics. New York, NY, USA: Cambridge University Press.

History of Bipartisanship. (2019). Retrieved June 11, 2019, from Bipartisan Policy Center website: https ://bipartisanpolicy.org/history-of-bipartisanship-2/.

Hong, L., \& Page, S. (2004). Groups of diverse problem solvers can outperform groups of high-ability problem solvers. PNAS, 101(46), 16385-16389. https://doi.org/10.1073/pnas.0403723101.

Hornung, J., Bandelow, N. C., \& Vogeler, C. S. (2018). Social identities in the policy process. Policy Sciences, 52(2), 211-231. https://doi.org/10.1007/s11077-018-9340-6.

Howlett, M., Ramesh, M., \& Wu, X. (2015). Understanding the persistence of policy failures: The role of politics, governance and uncertainty. Public Policy and Administration, 30(3), 209-220. https:// doi.org/10.1177/0952076715593139.

Izquierdo, S., Izquierdo, L., \& Gotts, N. (2008). Reinforcement learning dynamics in social dilemmas. Journal of Artificial Societies and Social Simulation, 11(2), 1.

Jacobs, T. (2018). Authoritarianism: The terrifying trait that trump triggers. Pacific Standard. Retrieved July 14, 2019 from https://psmag.com/news/authoritarianism-the-terrifying-trait-that-trump-trigg ers.

Janis, I. L. (1972). Victims of groupthink. Boston: Houghton Mifflin.

Jerit, J., \& Barabas, J. (2012). Partisan perceptual bias and the information environment. The Journal of Politics, 74(3), 672-684. https://doi.org/10.1017/S0022381612000187.

Kakkar, H., \& Sivanathan, N. (2017). Why we prefer dominant leaders in uncertain times. Harvard Business Review. Retrieved July 2, 2019 from https://hbr.org/2017/08/why-we-prefer-dominant-leadersin-uncertain-times.

Kamer, G. (2018). Hyper-partisanship and the Prisoner's Dilemma. Harvard Political Review. Retrieved May 25, 2019, from https://harvardpolitics.com/united-states/hyper-partisanship-and-the-prisonersdilemma/.

Kavanagh, J., \& Rich, M. D. (2018). Truth decay: An initial exploration of the diminishing role of facts and analysis in American Public Life [Product Page]. Retrieved June 4, 2019, from RAND Corporation website: https://www.rand.org/pubs/research_reports/RR2314.html.

Kenton, W. (2018). Centipede game. Retrieved June 11, 2019, from https://www.investopedia.com/terms/c/ centipede-game.asp.

Krehbiel, K., Meirowitz, A., \& Wiseman, A. (2015). A theory of competitive partisan lawmaking. Political Science Research and Methods, 41, 1-26.

Kreps, D. M., Milgrom, P., Roberts, J., \& Wilson, R. (1982). Rational cooperation in the finitely repeated prisoners' dilemma. Journal of Economic Theory, 27(2), 245-252. https://doi.org/10.1016/00220531(82)90029-1.

Lee, F. E. (2015). How party polarization affects governance. Annual Review of Political Science, 18(1), 261-282. https://doi.org/10.1146/annurev-polisci-072012-113747.

Leonhardt, D., Philbrick, I. P., \& Thompson, S. A. (2017). Opinion. Trump's Lies vs. Obama's. The New York Times. Retrieved March 4, 2019 from https://www.nytimes.com/interactive/2017/12/14/opinion/ sunday/trump-lies-obama-who-is-worse.html.

Levitsky, S., \& Ziblatt, D. (2018). How democracies die. New York: Crown Publishing Group. ISBN 978-1-5247-6293-3.

Linster, B. G. (1992). Evolutionary stability in the infinitely repeated prisoners' dilemma played by twostate Moore machines. Southern Economic Journal, 58(4), 880-903.

List of United States political appointments across party lines. (2019). Retrieved June 10, 2019, from Wikipedia website https://en.wikipedia.org/wiki/List_of_United_States_political_appointments_acros s_party_lines.

Lofgren, M. (2011). Goodbye to all that: Reflections of a gop-operative who left the cult. https://www.truth -out.org.

Lofgren, M. (2012). The party is over: How republicans went crazy, democrats became useless, and the middle class got shafted. Viking Books.

Lofgren, M. (2013). The Authoritarian Seduction. truthout.org. Retrieved June 1, 2019 from https://truthout. org/articles/the-authoritarian-seduction/.

MacWilliams, M. (2016). The one weird trait that predicts whether you're a Trump supporter. Politico Magazine. Retrieved June 21, 2019 from http://www.politico.com/magazine/story/2016/01/donald-trump -2016-authoritarian-213533.

Macy, M., \& Flache, A. (2002). Learning dynamics in social dilemmas. PNAS, 99(3), 7229-7236. 
Mann, T., \& Ornstein, N. (2012). It's even worse than it looks: How the American constitutional system collided with the new politics of extremism. Basic Books. ISBN 9780465031337.

Mann, T., \& Corrado, A. (2014). Party Polarization and Campaign Finance. Center for Effective Public Management at Brookings, July 2014. Retrieved September 2, 2019 from https://www.brookings.edu/ wp-content/uploads/2016/06/Mann-and-Corrad_Party-Polarization-and-Campaign-Finance.pdf.

Martin, D. D. (2019). McConnell declares Senate a 'legislative graveyard,' blocks 400 bills from House Democrats. Source Politics. Retrieved July 27, 2019 from https://sourcepolitics.com/mcconnell-isblocking-as-many-bills-as-he-can-right-now/.

Masket, S. (2017). The case for democratic recklessness. Pacific Standard. Retrieved May 11, 2019 from https://psmag.com/news/the-case-for-democratic-recklessness.

Matzko, P. (2019). The fairness doctrine was terrible for broadcasting and it would be terrible for the internet. Cato Institute. Retrieved September 20, 2109 from https://www.cato.org/blog/internet-regulation -fairness.

McCauley, C. (1989). The nature of social influence in groupthink: Compliance and internalization. Journal of Personality and Social Psychology, 57, 250-260.

McConnell, A., \& 't Hart, P. (2019). Inaction and public policy: understanding why policymakers 'do nothing'. Policy Sciences, 52(4), 645-661.

Mody, A., \& Curcie C. (2011). The new imperial presidency. Harvard Political Review.

Molander, P. (1985). The optimal level of generosity in a selfish, uncertain environment. Journal of Conflict Resolution, 29, 611-618.

Moss, D. (2012). Fixing what's wrong with U.S. Politics. Harvard Business Review. Retrieved February 2 , 2019 from https://hbr.org/2012/03/fixing-whats-wrong-with-us-politics.

Moscovici, S., \& Zavalloni, M. (1969). The group as a polarizer of attitudes. Journal Of Personality and Social Psychology, 12(2), 125-135. https://doi.org/10.1037/h0027568.

Narea, N. (2019). A rare bipartisan agreement on immigration reform has tanked in the Senate. Vox.com. Retrieved from https://www.vox.com/policy-and-politics/2019/9/19/20873985/bipartisan-immigratio n-green-card-bill-senate.

Northcott, R., \& Alexandrova, A. (2015). Prisoner's dilemma doesn't explain much. In M. Peterson (Ed.), The prisoners' dilemma. Cambridge: Cambridge University Press. ISBN 9781107621473.

O'Donnell, N. (2016). Are members of Congress becoming telemarketers? CBS News, Script from 60 Minutes, "Dial for Dollars," April 24 2016. Retrieved September 7, 2019, from https://www.cbsne ws.com/news/60-minutes-are-members-of-congress-becoming-telemarketers/.

Ongstad, M. (2019). Trump doesn't fit our stereotype of foreign dictators-Because he's an American authoritarian. The Hill.com. Retrieved July 3, 2019 from https://thehill.com/opinion/white-house /447970-trump-doesnt-fit-stereotype-of-dictators-because-hes-an-american-authoritarian.

Paul, K. T., \& Haddad, C. (2019). Beyond evidence versus truthiness: Toward a symmetrical approach to knowledge and ignorance in policy studies. Policy Sciences, 52(2), 299-314. https://doi. org/10.1007/s11077-019-09352-4.

Paulus, P., \& Nijstad, B. (2003). Group creativity: Innovation through collaboration. Oxford Univerity Press.

Paur, K. (2016). Democrats and the Prisoner's Dilemma. Medium. Retrieved February 16, 2019 from https://medium.com/@katherine.paur/democrats-and-the-prisoners-dilemma-1a6c58274dc.

Perl, A., Howlett, M., \& Ramesh, M. (2018). Policy-making and truthiness: Can existing policy models cope with politicized evidence and willful ignorance in a "post-fact" world? Policy Sciences, 51(4), 581-600. https://doi.org/10.1007/s11077-018-9334-4.

Pettigrew, T. F. (2017). Social psychological perspectives on Trump supporters. Journal of Social and Political Psychology, 5(1), 107-116.

Pew Research Center. (2018). Public expects gridlock, deeper divisions with changed political landscape. Retrieved June 9, 2019, from Pew Research Center website: https://www.people-press .org/2018/11/15/public-expects-gridlock-deeper-divisions-with-changed-political-landscape/.

Pew Research Center. (2019). Political independents: Who they are, what they think. Retrieved June 10, 2019, from Pew Research Center website https://www.people-press.org/2019/03/14/political-indep endents-who-they-are-what-they-think/.

Picardo, E. (2019). The Prisoner's Dilemma in business and the economy. Retrieved May 25, 2019, from Investopedia website: https://www.investopedia.com/articles/investing/110513/utilizing-prisonersdilemma-business-and-economy.asp.

Poundstone, W. (1992). Prisoner's Dilemma/John Von Neumann, game theory and the puzzle of the bomb. Anchor Books/Doubleday. 
Pramuk, J. (2018). Immigration reform: More than a decade of failure from Bush to Obama and now Trump. CNBC.com. Retrieved March 7, 2019 from https:/www.cnbc.com/2018/06/29/congressunlikely-to-pass-immigration-reform-border-separation-bill.html.

Press, W. H., \& Dyson, F. (2012a). Iterated Prisoner's Dilemma contains strategies that dominate any evolutionary opponent. PNAS, 109(26), 10409-10413. https://doi.org/10.1073/pnas.1206569109.

Press, W. H., \& Dyson F. (2012b). On "Iterated Prisoner's Dilemma contains strategies that dominate any evolutionary opponent.” Edge.org. Retrieved January 11, 2019 from https://www.edge.org/ conversation/william_h_press-freeman_dyson-on-iterated-prisoners-dilemma-contains-strategies -that.

Raihani, N. J., \& Bshary, R. (2011). Resolving the iterated Prisoner's Dilemma: Theory and reality. Journal of Evolutionary Biology, 24(8), 1628-1639. https://doi.org/10.1111/j.1420-9101.2011.02307 .x.

Rauch, J. (2016). How American politics became so ineffective. The Atlantic. Retrieved November 1, 2018 from https://www.theatlantic.com/magazine/archive/2016/07/how-american-politics-wentinsane/485570/.

Rendall, S. (2005). The fairness doctrine how we lost it, and why we need it back. fair.org. Retrieved September 28, 2019 from https://fair.org/extra/the-fairness-doctrine/Rudalevige, Andrew. The New Imperial Presidency: Renewing Presidential Power after Watergate. Ann Arbor: University of Michigan Press.

Sallet, J., O’Melveny, \& Myers. (2011). Politics and the prisoners' dilemma. The Hill. Retrieved October 23, 2018 from https://thehill.com/blogs/congress-blog/politics/179361-politics-and-the-prisonersdilemma.

Satell, G. (2015). How to build trust, even with your enemies. Digital Tonto. Retrieved June 10, 2019, from https://www.digitaltonto.com/2015/how-to-build-trust-even-with-your-enemies/.

Stenner, K. (2005). The authoritarian dynamic. Cambridge: Cambridge University Press. https://doi. org/10.1017/CBO9780511614712. ISBN 978-0-511-61471-2.

Summers, J. (2018) AP-NORC Poll: Most Americans see a sharply divided nation. Retrieved March 4, 2019 from https://apnews.com/571f60848e0745678304b721303cdca0.

Sunstein, C. R. (2019). '1984' Comes to 2019. Bloomberg opinion. Retrieved July 27, 2019 from https:// www.bloomberg.com/opinion/articles/2019-07-18/trump-s-2019-and-orwell-s-1984-have-too-muchin-common.

Schlesinger, A. M., Jr. (1973). The imperial presidency. Boston: Houghton Mifflin Company.

Schultz, D. (2008). Stupid public policies and other political myths or (ten stupid things that government does that don't work and waste your money and why they do them). Paper presented at the American Political Science Association Annual Convention, Chicago, Illinois. August 29-September 2, 2007.

Seltzer, L. (2016). The Prisoner's Dilemma and the "Virtues" of Tit for Tat. Psychology Today. Retrieved March 11, 2019 from https://www.psychologytoday.com/blog/evolution-the-self/201607/the-prisoners-dilemma-and-the-virtues-tit-tat.

Seyle, C., \& Newman, M. (2006). A house divided? The psychology of red and blue America. American Psychologist, 61, 571. https://doi.org/10.1037/0003-066X.61.6.571.

Shepard, A. (2017). Will the fantasy of a unity ticket just die already? The New Republic. Retrieved March 4, 2019 from https://newrepublic.com/article/144669/will-fantasy-unity-ticket-just-die-already.

Sheposh, J. P., \& Gallo, P. S. (1973). Asymmetry of payoff structure and cooperative behavior in the prisoner's dilemma game. Journal of Conflict Resolution. Retrieved February 2, 2019 from https://doi. org/10.1177/002200277301700208.

Skyrms, B. (2001). The Stag Hunt. Proceedings and Addresses of the American Philosophical Association, 75(2), 31-41. https://doi.org/10.2307/3218711.

Skyrms, B. (2004). The stag hunt and the evolution of social structure. Cambridge, New York: Cambridge University Press. ISBN 0521533929.

Smith, J. (2018). We need a disunity ticket. Retrieved June 10, 2019, from Rolling Stone website https:// www.rollingstone.com/politics/politics-features/biden-romney-2020-768307/.

Stein, J. (2016). Most experts think America is more polarized than ever. This Stanford professor disagrees. Vox. Retrieved July 4, 2019 from https://www.vox.com/policy-and-politics/2016/11/1/13351284/ america-polarization.

Stewart, A. J. (2015). New take on game theory offers clues on why we cooperate. The Conversation. Retrieved March 3, 2019 from https://theconversation.com/new-take-on-game-theory-offers-clues-onwhy-we-cooperate-38130.

Stewart, A. J., \& Plotkin, J. B. (2013). From extortion to generosity, evolution in the Iterated Prisoner's Dilemma. Proceedings of the National Academy of Sciences, 110(38), 15348-15353. https://doi. org/10.1073/pnas.1306246110. 
Taub, A. (2016). The rise of American authoritarianism. Vox.com. Retrieved June 30, 2019 from https:// www.vox.com/2016/3/1/11127424/trump-authoritarianism.

Tetlock, P. (1979). Identifying victims of groupthink from public statements of decision makers. Journal of Personality and Social Psychology, 37, 1314-1324. https://doi.org/10.1037/0022-3514.37.8.1314.

The Economist. (2013). "You can't spend your way out of a Prisoner's Dilemma." Retrieved January 11, 2019 from https://www.economist.com/democracy-in-america/2013/06/07/you-cant-spend-your-wayout-of-a-prisoners-dilemma.

The Economist. (2018). The mid-terms produce a divided government for a divided country. Retrieved November 12, 2018 from https://www.economist.com/leaders/2018/11/08/the-mid-terms-produce-adivided-government-for-a-divided-country

Theodoridis, A. G. (2016). The hyper-polarization of America. Scientific American. Retrieved June 30, 2019 from https://blogs.scientificamerican.com/guest-blog/the-hyper-polarization-of-america/.

Thompson, F. J., Gusmano, M. K., \& Shinohara, S. (2018). Trump and the Affordable Care Act: Congressional repeal efforts, executive federalism, and program durability. Publius: The Journal of Federalism. Retrieved July 3, 2019 from https://academic.oup.com/publius/article/48/3/396/4982766.

Thurber, J. A., \& Yoshinaka, A. (Eds.). (2015). American gridlock: The sources, character, and impact of political polarization. Cambridge: Cambridge University Press. https://doi.org/10.1017/CBO9781316 287002. Online ISBN 9781316287002.

Tomasky, M. (2019). If we can keep it: How the republic collapsed and how it might be saved. Liveright Publishing. ISBN 9781631494086.

Tomasky, M. (2019b). Screw 'Uniting the Country'-That's Not What Democrats Need in 2020. Daily Beast. Retrieved March 3, 2019 from https://www.thedailybeast.com/screw-uniting-the-country-thats -not-what-democrats-need-in-2020.

Troiano, N. (2019). POLL: New Hampshire voters express broad support for a "Unity Ticket" in 2020. Unite America. Retrieved February 24, 2019 from https://www.uniteamerica.org/newhampshirepoll.

Troiano, N., \& Wheelan, C. (2019). The last presidential 'unity ticket' was in 1864 . We need another bipartisan pair in 2020. USA Today. Retrieved January 26, 2019 from https://www.usatoday.com/story /opinion/2019/01/17/bipartisan-presidential-unity-ticket-heal-divided-america-2020-column/25834 $04002 /$.

Turner, J. C. (2010). Social categorization and the self-concept: A social cognitive theory of group behavior. In T. Postmes \& N. R. Branscombe (Eds.), Key readings in social psychology: Rediscovering social identity (pp. 243-272). New York, NY: Psychology Press.

Wason, P. C. (1960). On the failure to eliminate hypotheses in a conceptual task. Quarterly Journal of Experimental Psychology, 12(3), 129-140. https://doi.org/10.1080/17470216008416717.

Weiser, W. R., \& Bannon, A. (Eds.). (2018). Democracy: An election agenda for candidates, activists, and legislators. New York: Brennan Center for Justice.

Wheelan, C. (2013). The Centrist Manifesto. W.W. Norton. ISBN: 9780393346879.

Wheelan, C. (2019). Our politics fails us, so here's what to do. The Economist. Retrieved March 23, 2019 from https://www.economist.com/open-future/2019/03/15/our-politics-fails-us-so-heres-what-to-do.

Whyte, G. (1998). Recasting Janis's groupthink model: The key role of collective efficacy in decision fiascos. Organization Behavior and Human Decision Processes, 73, 185-209.

Wu, J., \& Axelrod, R. (1995). How to cope with noise in the iterated prisoner's dilemma. Journal of Conflict Resolution, 39(1), 183-189. https://doi.org/10.1177/0022002795039001008.

Yu, R., \& Sun, S. (2013). To conform or not to conform: Spontaneous conformity diminishes the sensitivity to monetary outcomes. PLoS ONE, 8(5), e64530. https://doi.org/10.1371/journal.pone.0064530.

Zelizer, J. (2019). Nancy Pelosi is making a big mistake on impeachment. CNN. Retrieved June 22, 2019 from https:/www.cnn.com/2019/05/22/opinions/nancy-pelosi-is-making-a-big-mistake-on-impea chment-zelizer/index.html.

Zmigrod, L. (2019). The partisan brain: Cognitive study suggests people on the left and right are more similar than they think. The Conversation. Retrieved October 5, 2019 from https://theconversation.com/ the-partisan-brain-cognitive-study-suggests-people-on-the-left-and-right-are-more-similar-than-theythink-123578.

Publisher's Note Springer Nature remains neutral with regard to jurisdictional claims in published maps and institutional affiliations. 